\title{
Mucinous rectal adenocarcinoma in perianal Crohn's disease fistulas
}

\author{
Wing C PETER KWAN, MD, HUGH J FreEMan, MD
}

WCP KWAN, HJ FREEMAN. Mucinous rectal adenocarcinoma in perianal Crohn's disease fistulas. Can J Gastroenterol 1991;5(2):59-61. A 47-year-old male with longstanding Crohn's disease complicated by perianal fistulous disease is described. In this patient, presentation with a large acute ischiorectal abscess resulted in diagnosis of a complicating mucinous adenocarcinoma. Despite the relatively high frequency of perianal complications in Crohn's disease, diagnosis of carcinoma in this setting is difficult, and survival remains poor.

Key Words: Colorectal cancer, Crohn's disease, Fistula, Inflammatory bowel disease, Periaial Crohn's disease

\section{Adénome colloïde du rectum et fistules périanales de la maladie de Crohn}

RESUME: On rapporte le cas d'un patient âgé de 47 ans et porteur d'une maladie de Crohn de longue date, compliquée de fistules périanales. Chez ce patient, la présence d'un gros abcès chaud du creux ischiorectal a conduit au diagnostic d'un adénome colloïde. Malgré la fréquence relativement élevée des complications périanales de la maladie de Crohn, le diagnostic d'un carcinome est difficile dans ces circonstances et la survie reste mauvaise.

\footnotetext{
C
} ROHN'S DISEASE IS ASSOCIATED with an increased incidence of gastrointestinal tract carcinoma. Most reported cancers in Crohn's disease have appeared in the small intestine or in bypassed small intestinal loops. Although perianal disease is a common complication of Crohn's disease, car- cinoma arising in the anorectum is rare. In the present paper, a case of adenocarcinoma of the rectum is described in a patient with Crohn's disease presenting with perianal fistulas and abscess. Even though carcinoma complicating perianal Crohn's disease is an uncommon occurrence, awareness of this complica-

Department of Medicine (Gastroenterology), University Hospital; and University of British Columbia, Vancouver, British Columbia

Correspondence and reprints: Dr Peter Kwan, Gastroenterology, ACU F-137, University Hospital (UBC), 2211 Wesbrook Mall, Vancouver, British Columbia V6T 1 W5 Telephone (604) 228-7216

Received for publication November 7, 1990. Accepted February 6, 1991

tion should be heightened, since diagnosis is often difficult, and the prognosis following recognition is usually poor.

\section{CASE PRESENTATION}

A 47-year-old man had a diagnosis of Crohn's disease established in 1970, following presentation with right lower quadrant pain and presumed appendicitis. At laparotomy, a small bowel resection was performed. The patient subsequently developed an abdominal wall fistula that required eight months to heal. In 1980, he had an abdominal wall abscess drained and further resection of $19.5 \mathrm{~cm}$ of small intestine. Subsequently, the patient remained well except for intermittent diarrhea and a small anal fistula initially detected in 1986 because of a slight anal discharge. This resolved without treatment.

The patient was first referred in January 1990 because of recurrent diarrhea. Examination was normal except for a slightly tender nonfluctuant area of induration at the anorectal verge. No fissure, fistula or abscess was present. Flexible sigmoidoscopy to $35 \mathrm{~cm}$ did not show any mass lesion, and the mucosa was normal. Rectal biopsy was normal. Other investigations, including blood. work and stool studies for bacteria and parasites, were normal. Because a small perianal abscess was suspected, the patient was treated with oral metronidazole $250 \mathrm{mg}$ tid. In March 1990, minimal intermittent drainage from the 


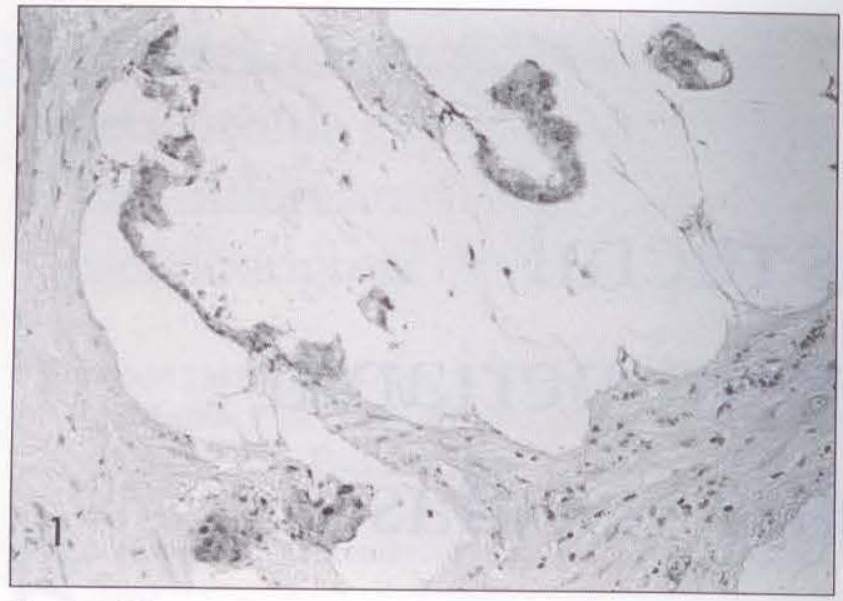

Figure 1) Biopsy specimen from wall of ischiorectal abscess showing an infiltrating mucinous adenocarcinoma characterized by clusters of malignant cells in large pools of mucin (hematoxylin and eosin $\times 73$ )

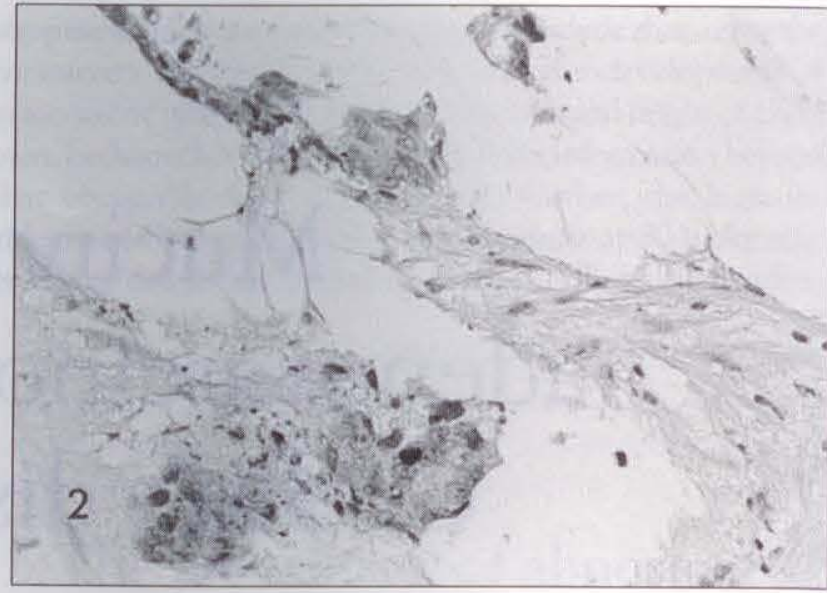

Figure 2) Higher magnification photomicrograph of same field in Figure 1 (hematoxylin and eosin $\times 292$ )

\section{TABLE 1}

\section{Cases of anorectal adenocarcinoma reported in Crohn's disease}

\begin{tabular}{|c|c|c|c|c|}
\hline $\begin{array}{l}\text { Year } \\
\text { (reference) }\end{array}$ & Age/sex & $\begin{array}{l}\text { Site of Crohn's } \\
\text { disease }\end{array}$ & $\begin{array}{l}\text { Duration of Crohn's } \\
\text { before cancer } \\
\text { diagnosis (years) }\end{array}$ & Presenting feature \\
\hline $1975(14)$ & $50 / \mathrm{F}$ & Ileocolitis & 30 & Perianal fistula \\
\hline $1980(15)$ & $45 / F$ & lleocolitis & 22 & Rectovaginal fistula \\
\hline $1981(16)$ & $30 / F$ & $\begin{array}{l}\text { Small bowel + } \\
\text { colon }\end{array}$ & 17 & Perineal fistulas \\
\hline 1987 (13) & $\begin{array}{l}34 / M \\
42 / M\end{array}$ & $\begin{array}{l}\text { Ileitis } \\
\text { Ileocolitis }\end{array}$ & $\begin{array}{l}14 \\
27\end{array}$ & $\begin{array}{l}\text { Anal stricture } \\
\text { Rectal bleeding }\end{array}$ \\
\hline $1988(17)$ & $\begin{array}{l}46 / M \\
64 / M \\
43 / M\end{array}$ & $\begin{array}{l}\text { \|leocolitis } \\
\text { Ileocolitis } \\
\text { \|leocolitis }\end{array}$ & $\begin{array}{l}22 \\
28 \\
10\end{array}$ & $\begin{array}{l}\text { Perianal fistula } \\
\text { Perianal fistula } \\
\text { Rectal ulcer }\end{array}$ \\
\hline Present case & $47 / M$ & Ileocolitis & 20 & Perineal fistulas \\
\hline
\end{tabular}

perianal area was described; examination was unchanged and metronidazole was continued.

In July 1990, the patient presented to the emergency room with four days of fever and severe perianal pain. Perianal drainage had increased significantly during the previous one to two weeks. Examination revealed a temperature of $40.5^{\circ} \mathrm{C}$. Three fistulous openings were present in the perianal region with a large, tender, horseshoeshaped, fluctuant, 6 to $7 \mathrm{~cm}$ ischiorectal abscess extending around the posterior rectum. Surgical drainage of the abscess was required; excisional biopsy of the perianal fistula revealed a mucinous adenocarcinoma (Figures 1,2). Preoperative evaluation with colonoscopy and small bowel barium radiographs revealed a focal area of induration just inside the anal verge and narrowing of the ileocolic anastomosis; anastomotic biopsy demonstrated acute inflammation but no other evidence for active Crohn's disease.

An abdominal-perianal resection was done. Pathological examination tion margins to be free from tumour, but the muscularis propria was present. One of four regional lymph nodes was positive for carcinoma.

\section{DISCUSSION}

The association of Crohn's disease with carcinoma was initially described by Warren and Sommers in 1948 (1). This was followed by reports from Ginzburg et al (2) and Kornfeld et al (3). Since these earlier reports, carcinoma of the small bowel or colon has been increasingly recognized as a complication of Crohn's disease. The incidence of cancer in this setting is showed the proximal and distal resecextension of the adenocarcinoma into generally believed to escalate with in. creasing duration of the underlying Crohn's disease. Adenocarcinoma of the small intestine is the most frequent tumour reported in some studies, and bypassed loops of small intestine are the most frequently observed small bowel site for cancer development (4). Indeed, in one report up to $30 \%$ of all cases of small bowel carcinoma in Crohn's disease occurred in excluded segments (5). The incidence of colorectal carcinoma in Crohn's disease is also believed to be increased from four to 20 times the incidence of de novo colorectal carcinoma observed in the general population (6-8). In a comparative study of Crohn's disease and ulcerative colitis, the incidence of colorectal carcinoma in Crohn's disease was estimated to be comparable to that in ulcerative colitis patients with leftsided disease alone (6).

Cancer has occasionally been reported in association with various chronic fistulas in Crohn's disease. It has been suggested that chronic inflammation and irritation plus disordered immunoregulation in inflammatory bowel disease may predispose to carcinogenesis. However, despite the high frequency of perianal disease in patients with Crohn's disease, perianal cancer is not frequently observed. A long term follow-up study from the Mayo Clinic recorded only a single case of carcinoma at this site (9). Similarly, a quarter of a century of experience at St Mark's Hospital in London totals only two 
cases (10). Indeed, a review of the English literature found only eight well described cases of anorectal adenocarcinoma in association with Crohn's disease. In addition, five cases of squamous cell carcinoma and three cases of cloacogenic cancer have been described. Table 1 summarizes the cases of anorectal adenocarcinomas reported in Crohn's disease.

As in the present patient, all cases had Crohn's disease of long duration prior to diagnosis of cancer, with the average patient age at diagnosis being only 41 years. Most of these patients had perianal/perineal fistulas. The pathology not infrequently showed mucinous adenocarcinoma, as noted previously, as adenocarcinomas arising in the background of inflammatory bowel disease have a higher percentage of colloid adenocarcinoma compared to noncolitic colorectal cancer (11). The most recently reported patients had fistulous disease present for a prolonged period before diagnosis of cancer. In the present case, a perianal fistula with minor intermittent drainage was present for several years; no obvious

\section{REFERENCES}

1. Warren S, Sommers SC. Cicatrizing enteritis (regional enteritis) as a pathologic entity: Analysis of one hundred and twenty cases. Am J Pathol 1948;24:475-501.

2. Ginzburg L, Schneider KM, Dreizin $\mathrm{DH}$, Levinson C. Carcinoma of the jejunum occurring in a case of regional enteritis. Surgery 1956;39:347-51.

3. Kornfeld P, Ginzburg L, Adlersberg D. Adenocarcinoma occurring in regional enteritis. Am J Med 1957;23:493.

4. Greenstein AJ, Sachar DB, Pucillo A, et al. Cancer in Crohn's disease after diversion surgery: A report of seven carcinomas occurring in excluded bowel. Am J Surg 1978;135:86-90.

5. Senay E, Sachar DB, Keohane M, Greenstein A]. Small bowel carcinoma in Crohn's disease. Distinguishing features and risk factors. Cancer 1989;63:360-3.

6. Greenstein AJ, Sachar DB, Smith H, Janowitz HD, Aufses AH Jr. A comparison of cancer risk in Crohn's mass lesion was evident until the patient's rather dramatic presentation with fever, perianal pain, fistulous disease, and a large, rather acute ischiorectal abscess that required surgical excision and drainage.

Except for the ileocolic anastomosis that revealed some inflammatory change, evidence for active Crohn's disease was not present elsewhere in the small or large bowel. Although colorectal carcinoma may occur at the site of active Crohn's disease, including fistulas, the observation in the present patient is consistent with previous reports. Hamilton (12) observed colorectal cancers located in normal bowel in up to one-third of cases of Crohn's disease. Greenstein et al (13) further stressed this observation, and in their report of rectal carcinomas in Crohn's disease, the colon was otherwise normal by endoscopic, pathological or radiological evaluation.

Even though the association between Crohn's disease and carcinoma is recognized, there is considerable difficulty in formulating a surveillance program. Occult blood screening is un-

disease and ulcerative colitis. Cancer 1981;48:2742-5.

7. Korelitz BI. Carcinoma of the intestinal tract in Crohn's disease: Results of a survey conducted by the National Foundation for Ileitis and Colitis. Am J Gastroenterol 1983;78:44-6,

8. Weedon DD, Shorter RG, Ilstrup DM, Huizenga KA, Taylor WF. Crohn's disease and cancer. N Engl J Med 1973;289:1099-102.

9. Wolff BG, Culp CE, Beart RW, Ilstrup DM, Ready RL. Anorectal Crohn's disease: A longterm perspective. Dis Colon Rectum 1985;28:790-11.

10. Preston DM, Fowler EF, Lennard-Jones JE, Hawley PR. Carcinoma of the anus in Crohn's disease. Br J Surg 1983; 70:346-7.

11. Morson BC. Cancer in ulcerative colitis. Gut 1966;6:425-6.

12. Hamilton SR. Colorectal carcinoma in patients with Crohn's disease. Gastroenterology 1985;89:398-407.

13. Greenstein AJ, Meyers S, Szporn A, reliable, and the presence of surgical artefact and stricture makes endoscopic examinations difficult. Radiographic evaluations are difficult to interpret because of stricture, inflammatory changes, bypassed loops and fistulas. Furthermore, for colorectal carcinoma, even though colonoscopic biopsies may be possible, the relationship between mucosal dysplasia and carcinoma - as hypothesized for the dysplasia-cancer sequence in ulcerative colitis - is not yet firmly established (18).

It remains to be determined if there are any risk factors that can be identified in longstanding Crohn's disease, particularly with fistulous disease, that will increase the likelihood of carcinoma. Although perianal disease and fistulas are common, the presence of carcinoma is rare. Unfortunately, detection of carcinoma at present, appears to be dependent upon heightened suspicion and performance of liberal biopsies. In this setting, biopsy of fistulas may not be ideal. Moreover, the prognosis is universally poor if the diagnosis is made, with survival less than two years.

Slater G, Janowitz HD, Aufses AH Jr. Colorectal carcinoma in regional enteritis. Q J Med 1987;62:33-40.

14. Lightdale CJ, Sternberg SS, Posner G, Sherlock P. Carcinoma complicating Crohn's disease. Report of seven cases and review of literature. Am J Med 1975;9:262-8.

15. Buchmann P, Allan RN, Thompson $\mathrm{H}$, Alexander-Williams J. Carcinoma in a recto-vaginal fistula in a patient with Crohn's disease. Am J Surg 1980;140:462-3.

16. Chaikhouni A, Regueyra Fl, Stevens JR. Adenocarcinoma in perineal fistulas of Crohn's disease. Dis Colon Rectum 1981;24:639-43.

17. Ball SC, Wujanto R, Haboubi NY, Schofield PF. Carcinoma in anal Crohn's disease: Discussion paper. J R Soc Med 1988;81:217-9.

18. Riddell RH. The precarcinomatous phase of ulcerative colitis. In: Morson BC, ed. Current Topics in Pathology of the Gastrointestinal Tract. Berlin: Springer, 1976:179-219. 


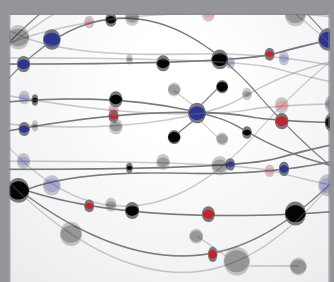

The Scientific World Journal


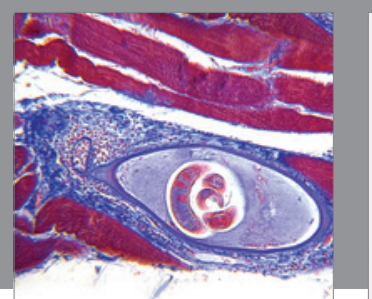

Gastroenterology Research and Practice

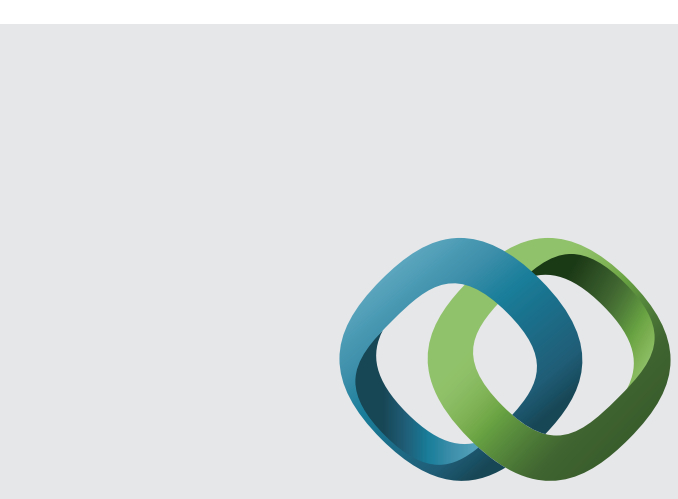

\section{Hindawi}

Submit your manuscripts at

http://www.hindawi.com
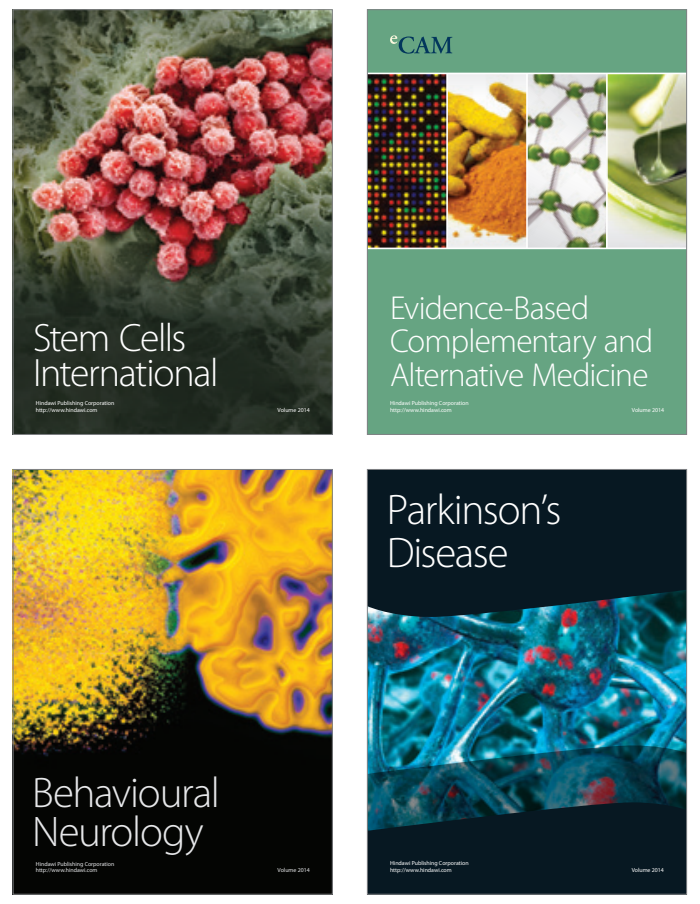
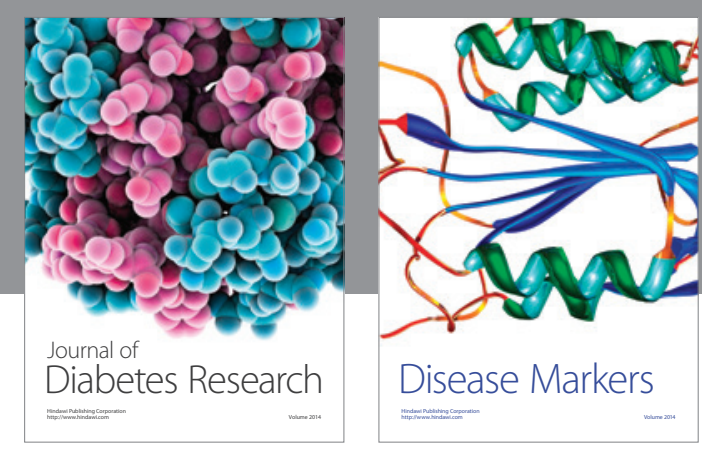

Disease Markers
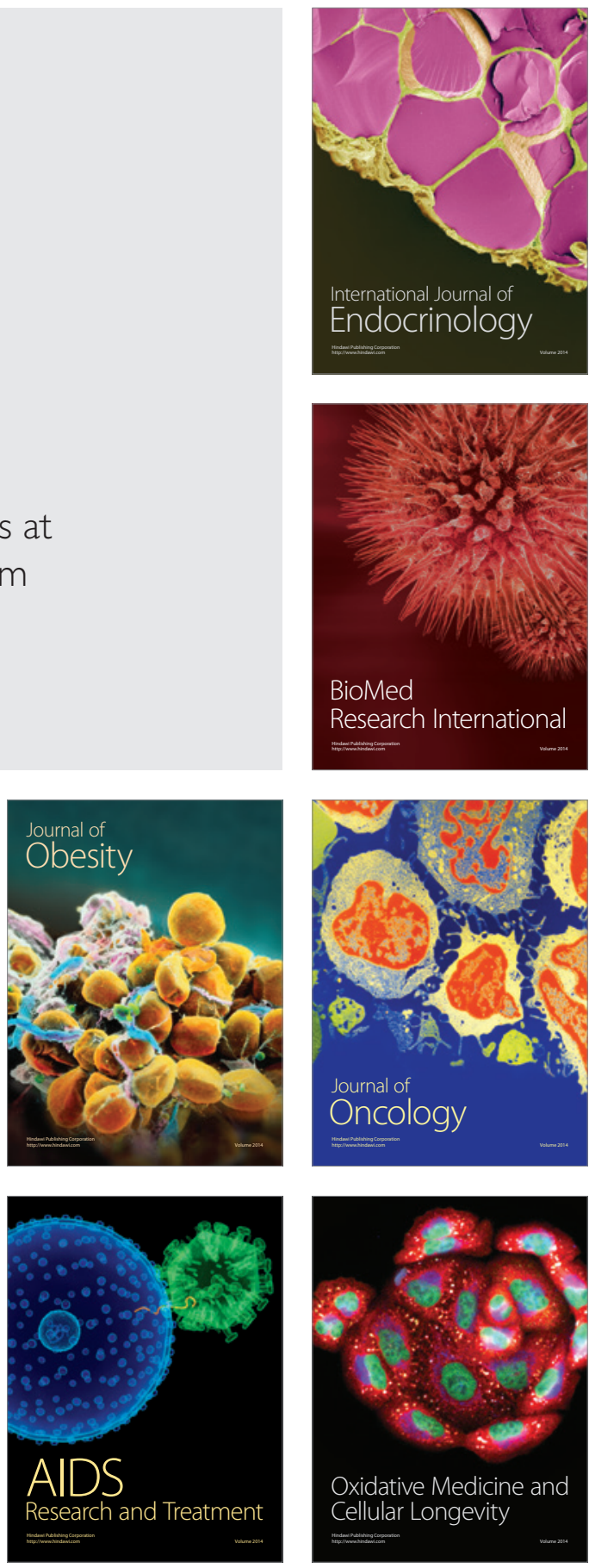